\title{
PERILAKU EARNINGS MANAGEMENT \\ DI SEKITAR PERUBAHAN TARIF PAJAK TAHUN 2008
}

(Studi Pada Perusahaan Perbankan

Di Bursa Efek Indonesia Yang Menyalurkan Kredit Kepada UKM)

\author{
Suyanto \\ Fakultas Ekonomi \\ Universitas Sarjanawiyata Tamansiswa Yogyakarta \\ E-mail: iyantsuyanto@gmail.com
}

\begin{abstract}
ABSTRAK
This study aims to test the level of earning management before and after the income tax rate reduction for 2008 fiscal year. The samples were 21 banking companies listed in Indonesia Stock Exchange, which has provides loans to SMEs.

The analysis using paired samplest-test to test these differences of earning management before and after the income tax rates changes. The results showed that earning management in the high tax rate was higher than in the lower tax rate. This shows that management has responded the income tax rates changes to take the opportunity.
\end{abstract}

Keywords: discretionary accruals, earnings management, corporate income tax changes.

\section{LATAR BELAKANG}

Kontribusi pajak dalam mendanai pengeluaran negara tak dapat dipungkiri sangat besar karena dalam kurun waktu 2006-2012, penerimaan perpajakan berkontribusi rata-rata $70 \%$ terhadap total pendapatan negara dan hibah. Akibat pentingnya sumber pajak ini juga dapat menimbulkan konflik antara wajib pajak dan pemerintah. Di satu sisi pemerintah berkeinginan untuk memungut pajak setinggi mungkin akibat berkurangnya pendapatan negara dari sektor lain, namun di sisi lain wajib pajak menginginkan membayar pajak sekecil mungkin. Akibatnya pihak wajib pajak akan mencarai berbagai macam cara untuk memperkecil pembayaran pajak. Salah satunya dengan memanipulasi laba perusahaan.

Perubahan peraturan perpajakan yang terjadi di Indonesia, bisa menjadi celah bagi perusahaan untuk dapat melakukan penghematan pajak. Perubahan tarif yang terjadi pada wajib pajak badan yaitu adanya penurunan tarif selama dua tahun berturutturut, pada tahun 2008 terjadi perubahan tarif pajak dari tarif progresif ke tarif proportional menjadi $28 \%$, yang berlaku mulai tahun 2009, kemudian perubahan tarif terjadi lagi pada tahun 2009 terjadi penurunan tarif kembali dari $28 \%$ menjadi $25 \%$ yang berlaku pada tahun 2010. Manajemen bisa melakukan tax shifting yaitu memindahkan pendapatan ke tahun yang memiliki tarif yang lebih rendah.

Pada beberapa penelitian sebelumnya antara lain oleh Wijaya dan Martani (2011) serta Setiawati dan Naim (2001) menemukan bahwa perusahaan melakukan tindakan manajemen laba dalam menanggapi penurunan tarif pajak badan di Indonesia, baik perusahaan yang mengalami keuntungan maupuan perusahaan yang mengalami kerugian selain itu juga ditemukan bahwa perusahaan yang memperoleh keuntungan melakukan praktik manajemen laba yang lebih besar dibandingkan dengan perusahaan yang mengalami kerugian. Sementara penelitian yang menemukan hasil sebaliknya adalah Sitorus dan Handayani (2010), Setiawati 
(2000) serta Hidayati dan Zulaikha (2003) tidak menemukan bukti empiris terjadi indikasi manajemen laba.

Selama ini penelitian di Indonesia menggunakan sampel berdasarkan kelompok industri perusahaan yang terdaftar di Bursa Efek Indonesia dan belum ada yang meneliti sampel berdasarkan kebijakan perusahaan dalam menyalurkan kredit kepada UKM khususnya perusahaan dalam industri perbankan. Oleh karena itu penelitian ini akan mengambil sampel perusahaan perbankan yang ada di Bursa Efek Indonesia dengan tiga periode tarif pajak yang berbeda yaitu tahun 2008 dan 2010 .

\section{PERUMUSAN MASALAH}

Berdasarkan uraian pada latar belakang tersebut, peneliti memfokuskan masalah yang dirumuskan sebagai berikut: Apakah terjadi perilaku manajemen laba melalui discretionary accrual dalam merespon penurunan tarif pajak penghasilan Badan tahun 2008, pada perusahaan perbankan yang menyalurkan kredit kepada UKM?

\section{TUJUAN PENELITIAN}

Berdasarkan perumusan masalah, tujuan penelitian ini adalah sebagai berikut:

1. Untuk menguji apakah penurunan tarif pajak penghasilan Badan tahun 2008 akan direspon oleh wajib pajak Badan perbankan yang menyalurkan kredit kepada UKM dengan melakukan manajemen laba.

2. Untuk memperoleh bukti empiris tentang ada tidaknya perbedaan tingkat discretionary accrual pada perbankan yang menyalurkan kredit kepada UKM sebelum dan sesudah penurunan tarif pajak penghasilan Badan 2008.

\section{MANFAAT PENELITIAN}

Penelitian ini diharapkan bisa memberikan manfaat sebagai beikut.

1. Hasil dari penelitian ini bisa dijadikan bahan pertimbangan bagi penelitian selanjutnya.
2. Hasil penelitian bisa digunakan sebagai referensi oleh pihak investor perusahaan agar lebih jeli dalam melihat laba yang dilaporkan perusahaan.

3. Hasil penelitian ini juga bisa digunakan oleh pemerintah dalam hal ini adalah Direktorat Jenderal Pajak agar mengetahui manajemen laba yang diketahui oleh perusahaan dalam rangka meminimalkan pajaknya.

\section{LANDASAN TEORI}

\section{Laba}

Laba secara operasional merupakan perbedaan antara pendapatan yang direalisasi yang timbul dari transaksi selama satu periode dengan biaya yang berkaitan dengan pendapatan tersebut. Pengertian laba menurut IAI dalam adalah kenaikan manfaat ekonomi selama satu periode akuntansi dalam bentuk pemasukan atau penambahan aktiva atau penurunan kewajiban yang mengakibatkan kenaikan ekuitas yang tidak berasal dari kontribusi peranan modal. Besar kecilnya laba sebagai pengukur kenaikan sangat bergantung pada ketepatan pengukuran pendapatan dan biaya. Belkaoui dalam Chariri dan Ghozali dalam Lestari, Budi (2011) menyebutkan bahwa laba memiliki beberapa karakteristik antara lain sebagai berikut:

a. Laba didasarkan pada transaksi yang benar-benar terjadi

b. Laba didasarkan pada postulat periodisasi, artinya merupakan prestasi perusahaan pada periode tertentu.

c. Laba didasarkan pada prinsip pendapatan yang memerlukan pemahaman khusus tentang definisi, pengukuran dan pengakuan pendapatan.

d. Laba memerlukan pengukuran tentang biaya dalam bentuk biaya historis yang dikeluarkan perusahaan untuk mendapatkan pendapatan tertentu.

e. Laba didasarkan pada prinsip penandingan (matching) antara pendapatan dan biaya yang relevan dan berkaitan dengan pendapatan tersebut. Laba menunjukkan kinerja perusahaan yang berasal dari aktivitas 
operasionalnya Perbandingan yang tepat atas pendapatan dan biaya tergambar dalam laporan laba rugi. Penyajian laba melalui laporan laporan keuangan bertujuan untuk menyediakan informasi yang bermanfaat bagi pihak yang berkepentingan.

\section{Manajemen Laba}

Laporan keuangan adalah cerminan dari kondisi perusahaan karena memuat informasi mengenai laporan kinerja manajemen, laporan arus kas dan laporan perubahan posisi keuangan perusahaan. Dalam laporan keuangan biasanya yang dijadikan parameter utama adalah besarnya laba perusahaan. Dengan adanya penilaian kinerja manajemen tersebut dapat mendorong timbulnya perilaku menyimpang dari pihak manajemen perusahaan yang salah satu bentuknya adalah manjemen laba (earnings management). Manajemen laba merupakan tindakan manajemen untuk memilih kebijakan akuntansi dari suatu standar tertentu untuk mempengaruhi laba yang akan terjadi menjadi seperti yang mereka inginkan melalui "pengelolaan" faktor internal yang dimiliki atau digunakan perusahaan. (Sitorus dan Handayani, 2010). Scott dalam Sitorus dan Handayani (2010) mendefinisikan earnings management sebagai:

"Earnings management is the choice by a manager of accounting policies so as to achieve some specific objective".

Yang artinya earnings management adalah pilihan yang dilakukan oleh manajemen dalam menentukan kebijakan akuntansi untuk mencapai beberapa tujuan tertentu. Sedangkan Sugiri dalam Sitorus dan Handayani (2010), definisi earnings management di bagi dalam dua defenisi, yaitu :

a. Definisi Sempit

Bahwa earnings management hanya berkaitan dengan pemilihan metode akuntansi. Selain itu juga diartikan sebagai

komponen discretionary accrual dalam menetukan earnings. b. Definisi Luas

Earnings management merupakan tindakan manajer untuk meningkatkan atau mengurangi laba yang dilaporkan saat ini atas suatu unit dimana manajer bertanggung jawab tanpa mengakibatkan peningkatan atau penurunan profitabilitas ekonomi jangka panjang tersebut.

\section{Perubahan Tarif Pajak di Indonesia}

Perubahan untuk tarif $\mathrm{PPh}$ Badan yang terjadi di Indonesia adalah perubahan tarif UU PPh tahun 1983 yang mulai berlaku pada tahun 1984, perubahan tariff UU PPh tahun 1994 yang mulai berlaku pada tahun 1995, perubahan tariff UU PPh tahun 2000 yang mulai berlaku pada tahun 2001, dan perubahan UU PPh tahun 2008 yang mulai berlaku pada tahun 2009. Perubahan Undang-Undang Perpajakan terbaru di Indonesia terjadi tahun 2008 meliputi Undang-Undang Ketentuan Umum dan Tata Cara Perpajakan (UU KUP), UndangUndang Pajak Penghasilan (UU PPh), serta Undang-Undang Pajak Pertambahan Nilai Barang dan Jasa dan Pajak Penjualan Atas Barang Mewah (UU PPN dan PPnBM). Hal ini diatur berdasarkan Aturan Pelaksanaan Ketentuan Pasal 4 Peraturan Pemerintah Nomor 81 tahun 2007, UU No. 36 tahun 2008 tentang Perubahan Keempat atas Undang-Undang No. 7 tahun 1983 tentang Pajak Penghasilan dan dipertegas dengan Peraturan Menteri Keuangan PMK38/PMK.03/2008. Perubahan tarif yang terjadi pada wajib pajak badan yaitu adanya penurunan tarif pajak pada tahun 2008 dari tarif progresif ke tarif proportional menjadi $28 \%$, yang berlaku mulai tahun 2009 .

\section{PENELITIAN TERDAHULU}

Beberapa penelitian terdahulu yang menemukan adanya perilaku manajemen laba disekitar perubahan tarif pajak adalah: Guenther dalam Sitorus dan Sri Handayani (2007), Frankel dan Trezervent (1994) dalam Setiawati dan Naim (2001). Sedangkan yang menemukan hasil sebaliknya antara lain: penelitian oleh Sitorus dan Handayani (2010), Wijaya dan Martani (2011), 
Setiawati (2000) dan Hidayati dan Zulaikha (2003) yang dalam penelitiannya membuktikan bahwa perubahan UndangUndang Perpajakan tahun 2000 tidak direspon oleh Wajib Pajak Badan untuk melakukan earning management dengan tujuan untuk meminimumkan beban pajak penghasilan perusahaan
Penelitian ini untuk menguji apakah ada perbedaan signifikan discretional accruals di sekitar tahun terjadinya perubahan tarif pajak pada perusahaan perbankan yang listed di Bursa Efek Indonesia. Sehingga data yang digunakan adalah tahun 2008 dan 2009.

\section{RERANGKA KONSEPTUAL}

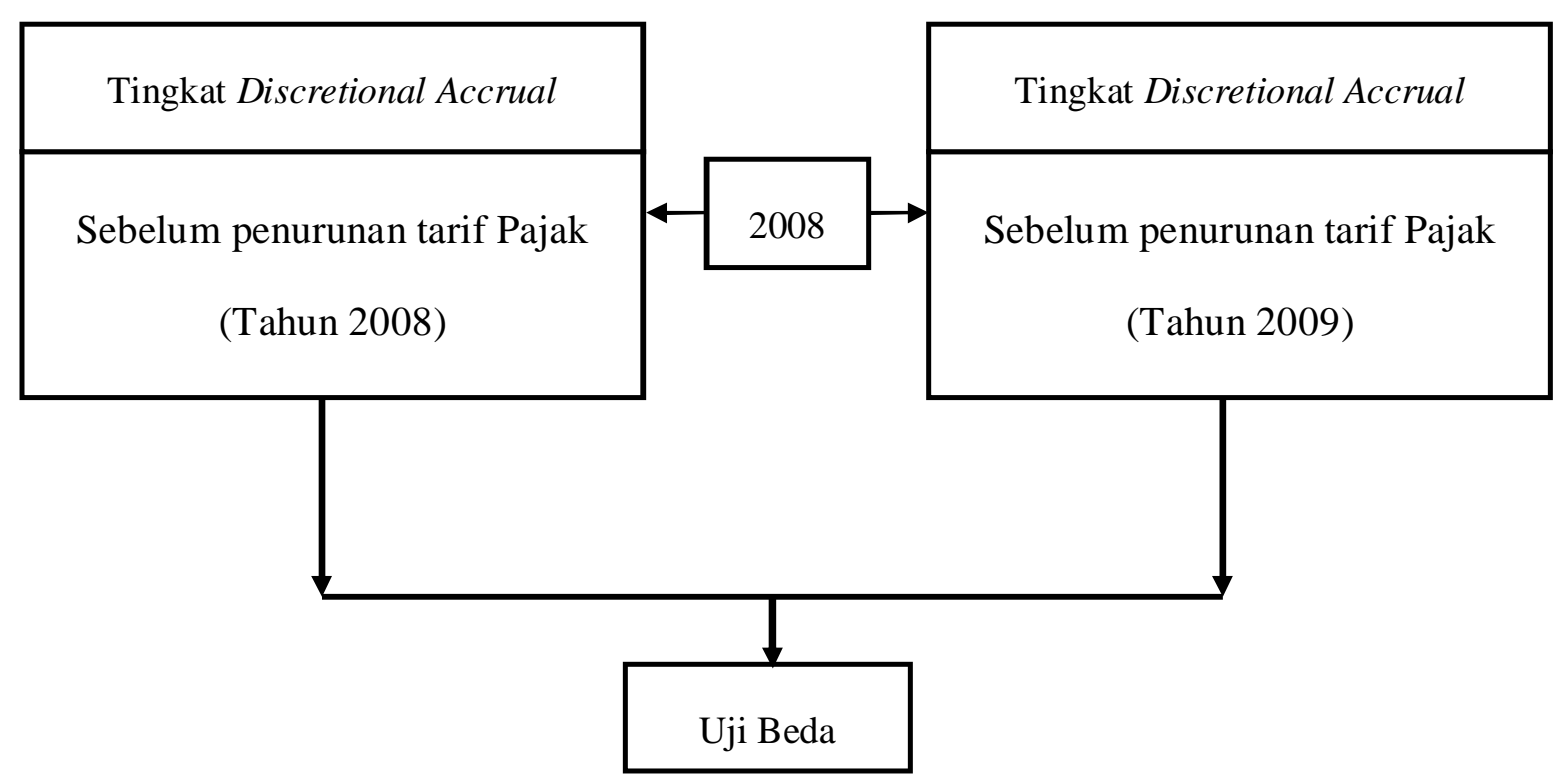

\section{Hipotesis Penelitian}

Hipotesis yang diajukan dalam penelitian ini adalah sebagai berikut:

H1: Tingkat discretionary accrual setelah penurunan tarif pajak penghasilan Badan Tahun 2008 lebih rendah daripada sebelum penurunan tarif pajak pada perusahaan Perbankan yang listed di Bursa Efek Indonesia.

H2: Ada perbedaan signifikan antara tingkat discretionary sebelum dan setelah penurunan tarif pajak penghasilan Badan Tahun 2008 pada perusahaan Perbankan yang listed di Bursa Efek Indonesia.

\section{METODE PENELITIAN}

\section{Populasi dan Sampel}

Penelitian ini merupakan penelitian kuantitatif yang menggunakan data sekunder. Data yang digunakan dalam penelitian ini adalah data sekunder berupa laporan keuangan Wajib Pajak Badan perusahaan perbankan yang terdaftar pada Bursa Efek Indonesia periode tahun 2008-2009. Pengambilan data laporan keuangan perusahaan perbankan melalui www.idx.co.id. Teknik pengambilan sampel yang digunakan adalah purposive sampling, yakni hanya mengambil bank-bank yang menyalurkan kredit kepada UKM.

\section{Variabel Penelitian}

Variabel dalam penelitian ini adalah earnings management (EM) yang di proksi discretionary accrual. Model untuk discretionary accrual akan menggunakan model Jones (1991) yang telah dimodifikasi oleh Dechow et al. (1995) yaitu sebagai berikut:

\section{Total Akrual}

$\mathrm{TACC}_{\text {it }}=\mathrm{NI}_{\text {it }}+\mathrm{CFO}_{\text {it }}$

Keterangan:

TACC $_{\text {it }}=$ Total akrual perusahaan $\mathrm{i}$ pada tahun $\mathrm{t}$ 
$\mathrm{NI}_{\mathrm{it}} \quad=$ Laba bersih perusahaan $\mathrm{i}$ pada tahun $\mathrm{t}$

$\mathrm{CFO}_{\mathrm{it}}=$ Kas dari operasi perusahaan i pada tahun $\mathrm{t}$

\section{Menentukan koefisien dari Regresi Akrual \\ Discretionary accrual adalah selisih antara total akrual (TACC) dengan nondiscretionary accrual (NDACC). Langkah awal untuk menentukan nondiscretionary accrual yaitu dengan melakukan regresi sebagai model berikut:}

$\mathbf{T A C C}_{\mathrm{it}} / \mathbf{T A}_{\mathrm{it}-1}=\alpha_{\mathrm{i}}+\beta_{1}\left(\mathbf{1} / \mathbf{T A} \mathbf{A}_{\mathrm{it}-1}\right)+$ $\beta_{2}\left(\left(\Delta R E V_{i t}-\Delta R C_{i t}\right) / \mathbf{T A}_{\text {it-1 }}\right)+$ $\boldsymbol{\beta}_{\mathbf{3}}\left(\mathbf{A T}_{\mathrm{it}} / \mathbf{T} \mathbf{A}_{\mathrm{it}-1}\right)$

Keterangan:

$\mathrm{TACC}_{\mathrm{it}}=$ Total akrual perusahaan i pada tahun $\mathrm{t}$

$\mathrm{TA}_{\mathrm{it}-1}=$ Total aktiva perusahaan $\mathrm{i}$ pada tahun t-1

$\mathrm{CFO}_{\text {it }}=$ Kas dari operasi perusahaan $\mathrm{i}$ pada tahun $\mathrm{t}$

$\triangle \mathrm{REV}_{\mathrm{it}}=$ Perubahan Pendapatan perusahaan i pada tahun $\mathrm{t}$ terhadap pendapatan tahun $\mathrm{t}-1$

$\triangle \mathrm{REC}_{\mathrm{it}}=$ Perubahan Piutang Usaha perusahaan i pada tahun $t$ terhadap pendapatan tahun $\mathrm{t}-1$

$\mathrm{AT}_{\mathrm{it}}=$ Aktiva tetap perusahaan $\mathrm{i}$ pada tahun $\mathrm{t}$

\section{Menghitung Nondiscretionary accrual}

Setelah melakukan regresi pada poin

$\mathrm{b}$, hasil koefisien pada $\boldsymbol{\beta}_{\mathbf{1}}, \boldsymbol{\beta}_{\mathbf{2}}, \boldsymbol{\beta}_{\mathbf{3}}$ kemudian digunakan untuk memprediksi Nondiscretionary accrual melalui persamaan:

NDACC $_{i t}=\beta_{1}\left(1 / \mathbf{T A}_{\text {it }-1}\right)+$ $\beta_{2}\left(\left(\Delta R E V_{i t}-\Delta R E C_{i t}\right) / T_{A_{i t-1}}\right)+$ $\boldsymbol{\beta}_{3}\left(\mathbf{A T}_{\mathrm{it}} / \mathbf{T A}_{\mathrm{it}-1}\right)+\mathbf{e}_{\mathrm{it}}$

Keterangan:
NDACC $_{i t}=$ Nondiscretionary accrual perusahaan i pada tahun $\mathrm{t}$

$\mathrm{TA}_{\mathrm{it}-\mathrm{1}}=$ Total aktiva perusahaan $\mathrm{i}$ pada tahun t-1

$\mathrm{CFO}_{\text {it }}=$ Kas dari operasi perusahaan i pada tahun $\mathrm{t}$

$\triangle \mathrm{REV}_{\mathrm{it}}=$ Perubahan Pendapatan perusahaan i pada tahun $t$ terhadap pendapatan tahun $\mathrm{t}-1$

$\triangle \mathrm{REC}_{\mathrm{it}}=$ Perubahan Piutang Usaha perusahaan i pada tahun $\mathrm{t}$ terhadap pendapatan tahun $\mathrm{t}-1$

$\mathrm{AT}_{\mathrm{it}}=$ Aktiva tetap perusahaan $\mathrm{i}$ pada tahun $\mathrm{t}$

\section{Menghitung Discretionary accrual}

Setelah hasil regresi poin c diatas maka Discretionary accrual bisa dihitung dengan mengurangkan total akrual dengan nondiscretionary accrual yang dinyatakan dengan persamaan berikut:

$\mathrm{DAC}_{\mathrm{it}}=\left(\mathrm{TACC}_{\mathrm{it}} / \mathbf{T A}_{\mathrm{it}-1}\right)-\mathrm{NDACC}_{\mathrm{it}}$

\section{HASIL DAN PEMBAHASAN}

Uji beda T-test digunakan dalam penelitian ini untuk menguji apakah ada perbedaan rata-rata dua sampel yang berhubungan, dimana dalam hal ini adalah discretionary accrual pada periode sebelum dan sesudah penurunan tarif pajak penghasilan Badan 2008 untuk tahun 2008 dan 2009.

Sampel penelitian adalah bank-bank yang terdaftar di Bursa Efek Indonesia (BEI) dan telah menyalurkan kredit bagi UKM/UMKM. Adapun periode penelitian hanya dua tahun yaitu tahun 2008 dan 2009, yaitu tahun disekitar perubahan tarif pajak yang terjadi pada tahun 2008. Berikut adalah daftar bank yang menjadi sampel penelitian.

Tabel 1 Daftar Sampel Bank

\begin{tabular}{ll}
\hline No & Bank \\
\hline 1 & ARTHA GRAHA INTERNATIONAL \\
2 & BUKOPIN \\
3 & BUMI ARTA \\
4 & BUMIPUTRA \\
\hline
\end{tabular}




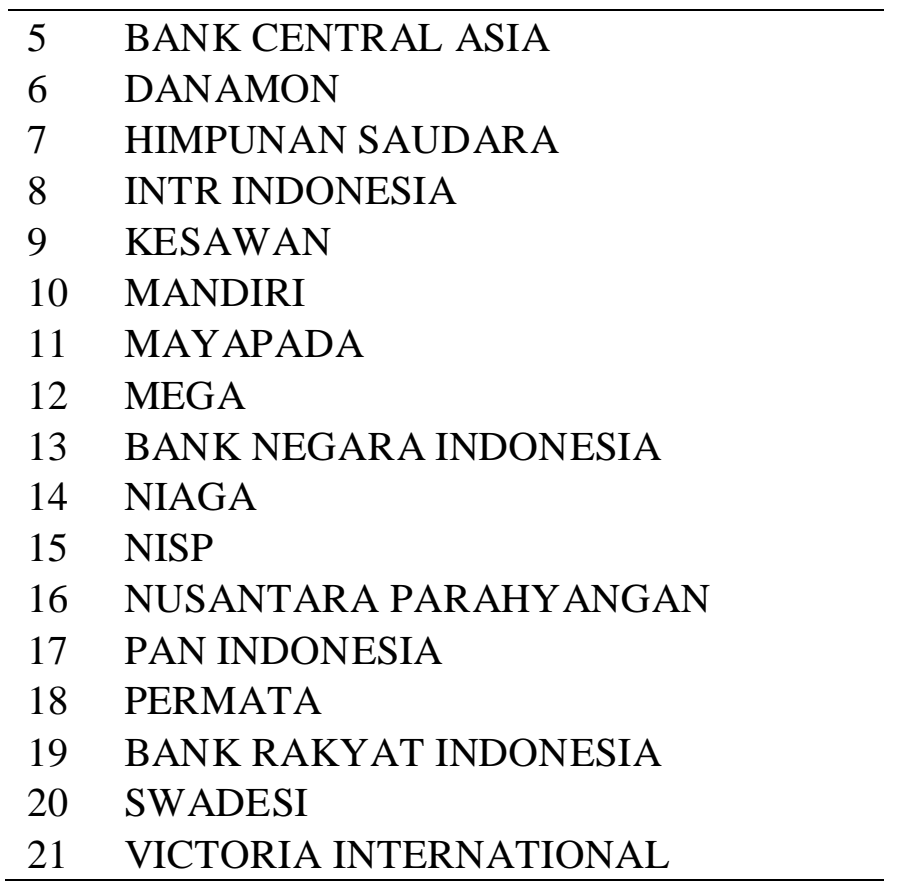

\section{Statistik Deskriptif}

Tabel 2 Statistik Deskriptif

\begin{tabular}{llcc}
\hline & $\begin{array}{l}\text { EM } \\
(\mathbf{2 0 0 8})\end{array}$ & Before & $\begin{array}{l}\text { EM } \\
(\mathbf{2 0 0 9 )}\end{array}$ \\
\hline Mean & -0.186 & -0.146 \\
After \\
Minimum & -0.347 & 0.063 \\
Maximum & -0.066 & -0.276 \\
N & 42 & -0.022 \\
\end{tabular}

Dari tabel diatas terlihat nilai manajemen laba (EM) pada 2008 dan 2009 masing-masing memiliki nilai minimum sebesar -0,347 dan -0,276 sedangkan nilai maksimumnya sebesar $-0,066$ dan $-0,022$. Rata-rata nilai manajemen laba pada tahun 2008 sebesar -0.186 dengan standar deviasi sebesar 0.068, ini lebih besar dari rata-rata manajemen laba tahun 2009 yaitu sebesar 0.146 dengan standar deviasi 0.063 . Manajemen laba yang bernilai negatif menunjukkan bahwa terdapat penuruan laba (income decreasing) atau dengan kata lain ada usaha penurunan laba pada kedua tahun tersebut. Penurunan yang lebih besar pada tahun 2008 dilakukan karena tarif pajaknya lebih tinggi sebelum adanya penurunan tarif.

\section{Model Prediksi dan Uji Asumsi Klasik}

Sebelum menghitung manajemen laba (dengan proksi discretionary accrual), terlebih dahulu ditentukan nilai nondiscretionary accrual dengan menggunakan model prediksi sebagai berikut:

TACC $_{i t} / \mathrm{TA}_{\mathrm{it}-1}=\alpha_{\mathrm{i}}+{ }_{1}\left(1 / \mathrm{TA}_{\mathrm{it}-1}\right)+$ ${ }_{2}\left(\left(\Delta R E V_{i t} \quad-\Delta R E C_{i t}\right) / T_{i t-1}\right) \quad+$ ${ }_{3}\left(\mathbf{A T}_{\mathrm{it}} / \mathbf{T A}_{\text {it-1 }}\right)$

Oleh karena menggunakan model regresi maka terlebih dahulu dilakukan pengujian asumsi klasik yang hasilnya diringkas dalam tabel berikut: 
Tabel 3. Uji Asumsi Klasik Model Prediksi

\begin{tabular}{llll}
\hline Normalitas & Autokorelasi & Heteroskedastisitas & Multikolinearitas \\
\hline Normal & Tidak Ada & Tidak Ada & Tidak Ada \\
\hline
\end{tabular}

Hasil uji asumsi klasik menunjukkan data telah memenuhi semua asumsi klasik sehingga dapat dilanjutkan dengan proses melakukan regresi, yang ditemukan nilai masing-masing koefisien $\boldsymbol{\beta}_{\mathbf{1}}, \boldsymbol{\beta}_{\mathbf{2}}$, dan $\boldsymbol{\beta}_{\mathbf{3}}$. Karena pada rumus Jones yang telah dimodifikasi tidak terdapat nilai konstan, maka nilai koefisien yang digunakan adalah Beta dari standardized coefficients, sebagai berikut:

\section{Tabel 4 Koefisien Model Prediksi}

\begin{tabular}{ll}
\hline & Koefisien \\
\hline $\boldsymbol{\beta}_{1}$ & -0.006 \\
$\boldsymbol{\beta}_{2}$ & 0.045 \\
$\boldsymbol{\beta}_{3}$ & 0.132 \\
\hline
\end{tabular}

Sehingga model yang digunakan untuk menghitung nondiscretionary accrual adalah sebagai berikut:

\author{
NDACC $_{\text {it }}=-0.006\left(1 / \mathrm{TA}_{\mathrm{it}-1}\right)+$ \\ $0.045\left(\left(\Delta R E V_{i t}-\Delta R E C_{i t}\right) / T_{i t-1}\right)$$$
+0.132\left(\mathrm{AT}_{\mathrm{it}} / \mathrm{TA}_{\mathrm{it}-1}\right)
$$

sesuai, maka diketemukan nilai nondiscretionary accrual untuk masingmasing sampel pada masing-masing tahun. Dengan demikian nilai akrual total dan nondiscretionary accrual sudah tersedia dan selanjutnya langkah terakhir adalah menemukan nilai discretionary accrual (sebagai proksi manajemen laba) sebelum dan sesudah penurunan tarif pajak dengan cara mengurangkan total akrual dengan nondiscretionary accrual dengan menggunakan rumus: $\mathbf{D A C}_{\mathbf{i t}}=$

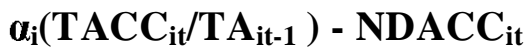

Setelah nilai discretionary accrual ditentukan maka selanjutnya adalah melakukan pengujian kedua hipotesis menggunakan uji beda dengan hasil:

Tabel 4.5 Pengujian Hipotesis

\begin{tabular}{|c|c|c|c|c|c|c|c|c|c|}
\hline & \multicolumn{5}{|c|}{ Paired Differences } & \multirow{3}{*}{ 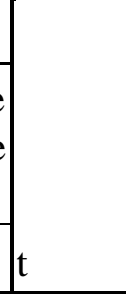 } & \multirow[b]{3}{*}{ df } & \multirow{3}{*}{$\begin{array}{l}\text { Sig. } \\
(2- \\
\text { tailed })\end{array}$} \\
\hline & & \multirow[b]{2}{*}{ Mean } & \multirow{2}{*}{$\begin{array}{l}\text { Std. } \\
\text { Deviati } \\
\text { on }\end{array}$} & \multirow{2}{*}{$\begin{array}{l}\text { Std. } \\
\text { Error } \\
\text { Mean }\end{array}$} & \multicolumn{2}{|c|}{$\begin{array}{l}95 \% \text { Confidence } \\
\text { Interval of the } \\
\text { Difference }\end{array}$} & & & \\
\hline & & & & & Lower & Upper & & & \\
\hline & $\begin{array}{l}\text { EM_Befor } \\
\text { e } \\
\text { EM_After }\end{array}$ & -.039 & .088 & .019 & -.080 & .0004 & -2.065 & 20 & .052 \\
\hline
\end{tabular}

Hipotesis pertama menyatakan bahwa nilai manajemen laba setelah penurunan Pajak akan lebih kecil daripada sebelum penurunan Pajak. Seperti terlihat pada tabel statistik deskriptif sebelumnya, rata-rata nilai manajemen laba setelah penurunan tarif pajak (2009) sebesar -0.146 atau lebih kecil dari rata-rata manajemen laba sebelum penurunan tarif pajak tahun (2008) yaitu sebesar -0.186 dan berdasarkan pengujian beda rata-rata pada tabel 4.5 diatas terbukti perbedaan manajemen laba tersebut adalah signifikan secara statistik. Sehingga hasil ini membuktikan kedua hipotesis penelitian, dimana pada hipotesis kedua menyatakan ada perbedaan signifikan antara tingkat 
manajemen laba sebelum dan setelah penurunan tarif pajak penghasilan Badan pada perusahaan Perbankan yang listed di Bursa Efek Indonesia. Hal-hal tersebut menunjukkan bahwa secara absolut, akrual tahun 2008 lebih rendah dan secara statistik ada perbedaan secara nyata, hal ini menandakan manajemen merespon kebijakan penurunan tarif pajak tersebut dengan menggunakan akrual untuk menghemat pajak Hasil ini telah sesuai dengan teori yang menyebutkan bahwa perusahaan akan memanfaatkan adanya kebijakan perubahan tarif pajak untuk keuntungan perusahaan yakni sedemikian rupa menjadikan beban pajak perusahaan menjadi lebih kecil. Penelitian terdahulu oleh Wijaya dan Martani (2011), Guenther (1994), Frankel dan Trezervent (1994) dalam Setiawati dan Naim (2001) juga menemukan hasil yang mendukung teori tersebut. Sementara hasil berbeda ditemukan oleh Sitorus dan Sri Handayani (2007), Setiawati (2000), serta Hidayati dan Zulaikha (2003).

Pada saat tarif pajak meningkat pihak manajemen akan semakin memperbesar manajemen labanya dengan tujuan untuk memperkecil nilai pajaknya, daripada jika tarif pajak menurun. Manajemen laba dapat dilakukan dengan cara mempercepat pengakuan terhadap pendapatan dan dalam waktu bersamaan menunda pengakuan beban. Dengan cara demikian besarnya laba pada tahun-tahun berikutnya akan terpengaruh. Untuk peristiwa dimana perubahan pajak yang dikenakan meningkat maka manajemen akan mempercepat pengakuan biaya dan menunda pengakuan pendapatan dengan tujuan laba menjadi berkurang dan pada akhirnya pajak yang dikenakan menjadi lebih kecil. Sebaliknya jika perubahan pajak adalah menurun maka manajemen mempercepat pengakuan pendapatan dan menunda pengakuan biaya agar laba yang disajikan dalam laporan keuangan menjadi lebih besar sehingga akan membuat kinerja perusahaan seolah-olah menjadi lebih baik. Disaat bersamaan perusahaan tidak perlu mengeluarkan pajak yang lebih besar karena tarif pajaknya sudah diturunkan oleh pemerintah. Oleh karena itu terdapat kemungkinan manajemen perusahaan tidak secara terus-menerus melakukan manajemen laba, tetapi hanya melakukan praktik manajemen laba pada periode tertentu untuk mencapai tujuan tertentu. Seperti halnya manajemen laba dilakukan pada periode disekitar pengumuman kebijakan perubahan tarif pajak.

Tindakan manajemen laba adalah hasil akuntansi akrual yang bertentangan dengan prinsip pelaporan keuangan sehingga dapat merusak kredibilitas informasi akuntansi dan mengurangi keandalan laporan keuangan. Tindakan merekayasa laba yang disajikan dalam laporan keuangan menyebabkan laporan keuangan tidak lagi mencerminkan nilai fundamental perusahaan yang sesungguhnya sehingga dapat menyesatkan para pengguna laporan keuangan dalam pengambilan keputusan. Saat melakukan rekayasa laba, sesungguhnya perusahaan menghadapi sebuah kontradiksi kepentingan. Di satu sisi manajemen ingin menampilkan kinerja keuangan yang baik dengan ditunjukkan dengan laba yang maksimal namun di sisi lain manajemen juga menginginkan untuk meminimalkan pajak yang dikenakan pada laba perusahaan.

Bagi pengguna laporan keuangan untuk kepentingan pengambilan kebijakan perlu berhati-hati terhadap celah kegiatan manajemen laba dengan tidak hanya terfokus dengan penggunaan indikator yang sudah umum digunakan selama ini seperti akuntansi akrual. Bhattacharya et al., (2003) mengatakan manajemen laba sesungguhnya juga dapat dilakukan empat items akrual yaitu: biaya amortisasi, peningkatan net accounts receivable, peningkatan inventory, dan penurunan accounts payble and accrual liabilities. Biaya amortisasi merupakan akrual non-diskresi, diasumsikan bahwa kebijakan mengenai amortisasi adalah given. Peningkatan piutang dagang diasumsikan berasal dari penurunan penyisihan piutang (allowance for doubtful account) yang merupakan hasil dari estimasi yang kurang konservatif. Hal ini merupakan akrual 
diskresi, karena manajemen secara fleksibel dapat mengendalikan jumlah penyisihan piutang tersebut; atau karena kebijakan kredit dan pencatatan saldo piutang pada awal dan akhir periode. Namun, jika peningkatan piutang disebabkan oleh peningkatan volume bisnis, maka akrual tersebut merupakan akrual non-diskresi. Demikian pula peningkatan inventory yang tidak disebabkan oleh perubahan volume merupakan akrual diskresi. Penurunan utang dagang dan kewajiban akrual juga merupakan akrual diskresi, dengan asumsi bahwa penurunan ini berasal dari manajemen yang lebih optimistic menjamin klaim terhadap produknya (Sunarto, 2009).

\section{SIMPULAN}

Simpulan yang dapat disampaikan dari penelitian ini adalah nilai manajemen laba setelah penurunan tarif pajak lebih kecil dari rata-rata manajemen laba sebelum penurunan tarif pajak tahun dan terdapat perbedaan signifikan terhadap manajemen laba pada perusahaan Perbankan yang listed di Bursa Efek Indonesia. Hal ini menunjukkan manajemen merespon kebijakan penurunan tarif pajak tersebut menggunakan akrual untuk menghemat pajak.

\section{SARAN}

Untuk penelitian berikutnya penulis menyarankan untuk menggunakan beberapa variabel lain seperti biaya amortisasi, peningkatan net accounts receivable, peningkatan inventory, dan penurunan accounts payble and accrual liabilities karena Beberapa penelitian lain menyatakan sesungguhnya manajemen laba tidak hanya dapat dideteksi dengan adanya kebijakan. Jika ditemukan ada hubungan antara variabel-variabel tersebut dengan manajemen laba maka hal tersebut akan menjadi kontribusi bagi pengambil keputusan untuk menjadi semakin jeli dalam melihat indikasi kegiatan manajemen laba yang dilakukan oleh perusahaan, sehingga terhindar dari pengambilan keputusan yang salah akibat tindakan manajemen laba oleh perusahaan.

\section{DAFTAR PUSTAKA}

Amali, Muhammad Naim. 2009. Analisis Deffered Tax Expense Dalam Mendeteksi Earnings Management Pada Wajib Pajak Emiten Yang Terdaftar di Kantor Pelayanan Pajak Perusahaan Masuk Bursa. Jurnal Akuntansi dan Bisnis Vol. 9, No. 1, Pebruari: 71-84. http://jurnal.pdii.lipi.go.id/index.php/Sear ch.html?act=tampil\&id=11924. Diakses tanggal 5 Agustus 2011

Arnawa, I Gede. 2006. Analisa Indikasi Manajemen Laba Melalui Discretionary Allowance For Loan Losses Pada Perbankan Pasca Rekapitalisasi. Thesis UI.

http://eprints.lib.ui.ac.id/2924/2/114885T\%2024104-Analisa\%20indikasiHA.pdf. Diakses tanggal 25 Agustus 2011.

Asworo, Hendri T. 2011. Peneingkatan Laba Perbankan Catat Rekor. http://bisnisjabar.com/index.php/2011/02/peningkata n-laba-perbankan-catat-rekor/ . Diakses tanggal 16 September 2011

Bhattacharya, U; H. Daouk; and M. Welker. 2003. "The World Price of Earnings Opacity." The Accounting Review, Vol. 78, No. 3, July: $641-678$.

Deviana, Birgitta. 2010. Kemampuan Beban Pajak Tangguhan dan Beban Pajak Kini Dalam Mendeteksi Manajemen Laba Pada Saat Seasoned Equity Offerings. Skripsi.

http://eprints.undip.ac.id/22320/1/birgita deviana_sp_C2C006035.pdf. diakses tanggal 27 Desember 2010

Dechow, P., Sloan, R., Sweeney, A., 1995, Detecting earnings management, The Accounting Review 70, 193-225.

Dhliwal, Dan, Cristi A. Gleason and Lilian F. Milss. 2003. Last Chance Earnings Management: Using the Tax Expense to Working 
Paper SSRN, http://www.ssrn.com . Diakses tanggal 14 Desember 2010.

Guenther, David A., 1994. "Earnings Management in Response to Corporate Tax Rate Changes: Evidence from the 1986 Tax Reform Act ", The Accounting Review, Vol.69, No. 1, pp. 230-243

Harjito, Martono. 2005. Manajemen Keuangan, Edisi Pertama, Cetakan Kelima, Yogyakarta: Penerbit Ekonisia Kampus Fakultas Ekonomi UII.

Hendarawan, D. Lucas. 2007. Analisis Pengaruh Deffered Tax Expense (DTE), Total Accruals (TAcc) dan Delta Operating Cash Flow (Delta CFO) Dalam Memprediksi Earnings Management Pada Perusahaan Perbankan di Bursa Efek Jakarta. Thesis UNAIR.

Lestari, Budi. 2011. Analisis Pengaruh Book Tax Differences terhadap Pertumbuhan Laba . http://eprints.undip.ac.id/. Diakes tanggal 5 Agustus 2011

Nachrowi D.N. 2002. Penggunaan Teknik Ekonometri. Cetakan Pertama. Jakarta: Penerbit Raja Grafindo Persada

Ngurah Agung, I Gusti. 2003. Statistika: Penerapan Metode Analisis Untuk Tabulasi Sempurna dan Tak Sempurna. Edisi I, Cetakan I, Jakarta: Raja Grasindo Persada

Noor, Rohaya Md, Nor'Azam Mastuki dan Zanariah Aziz. 2007. Earnings Management and Deferred Tax, Malaysian Accounting Review, Volume 6 No. 1

Philips, J., M. Pincus, and S. Rego. 2003. Earnings Management: New Evidence Based on Deferred Tax Expenses. Working Paper SSRN, http://www.ssrn.com . Diakses tanggal 14 Desember 2010.

Setiawati, Lilis dan Ainun Naim. 2001. Bank health evaluation by Bank
Indonesia and earnings management in banking industry. Gadjah Mada International Journal of Business. May: 159-176. $\quad$ http://ilib.ugm.ac.id/jurnal/detail.php?dataId=25 90. Diakes tanggal 26 Agustus 2011

Sitorus, Rumenta P. and Sri Handayani. 2010. Indikasi Manajemen Laba Seblum dan Sesudah Perubahan Tarif Pajak Penghasilan Badan Tahun. EngD thesis, Perpustakaan FE UNDIP. http://eprints.undip.ac.id/22943/ diakses tanggal 29 Juli 2011

Sunarto, 2009. Teori Keagenan dan Manajemen Laba, Jurnal Kajian Akuntansi, Februari 2009, Hal: 13 - 28

Wijaya, Maxson dan Dwi Martani. 2011. Praktik Manajemen Laba Perusahaan Dalam Menanggapi Tarif Pajak Sesuai UU No. 36 Tahun 2008. Simposium Nasional Akuntansi XIV: Universitas Syiah Kuala Banda Aceh.

Yulianti. 2005. “Kemampuan Beban Pajak Tangguhan dalam Mendeteksi Manajemen Laba". http://eprints.lib.ui.ac.id/16156/. Diakses tanggal 27 Desember 2010 